Implementasi Pembelajaran Collaborative Learning......

\title{
IMPLEMENTASI PEMBELAJARAN COLLABORATIVE LEARN- ING DALAM PENDIDIKAN AGAMA ISLAM DI SMK MA'ARIF NU TIRTO DAN SMKN I KEDUNGWUNI PEKALONGAN
}

\author{
Mufasiroh \\ SMK Ma'arif NU Tirto Pekalongan \\ mufasiroh32@gmail.com
}

\begin{abstract}
ABSTRAK:
Paradigma lama dalam proses pembelajaran adalah pendidik mentransfer pengetahuan kepada peserta didik secara pasif. Kondisi pembelajaran yang demikian masih mendominasi proses pembelajaran pada sebagian besar lembaga pendidikan. Guna mengatasi masalah tersebut dapat dilakukan dengan cara meningkatkan keikutsertaan peserta didik secara aktif dalam proses pembelajaran melalui kelompok-kelompok kecil kolaboratif. Temuan dalam penulisan ini bahwa implementasi pembelajaran Collaborative Learning pada mata pelajaran Pendidikan Agama Islam di SMK Ma'arif NU Tirto dan SMKN I Kedungwuni Pekalongan pada tahap persiapan dilakukan dengan menyusun Prota/Promes, Silabus dan RPP. Persiapan ini dilakukan pendidik sebelum pembelajaran dilaksanakan di dalam kelas. Tahap Pelaksanaan dilakukan dengan menggunakan tiga langkah kegiatan; Pendahuluan, Inti dan Penutup. Pembagian kelompok yang dilakukan pada kegiatan pendahuluan perlu lebih memperhatikan keberagaman peserta didik, sekalipun pada kegiatan inti pelaksanaan keaktifan peserta didik tampak pada saat melakukan kolaborasi. Presentasi yang merupakan kegiatan penutup Collaborative Learning dilakukan dengan memberi masukan, usul, saran dan pendapat dari kelompok lain, kemudian pendidik menyampaikan revisi jawaban yang menyimpang dari materi yang dipelajari. Pelaksanaan evalusai sudah mengarah pada pembelajaran aktif dengan menggunakan evaluasi proses dan hasil. Peran aktif
\end{abstract}

FENOMENA, Vol.19No.1April 2020 | 1 
Mufasiroh

peserta didik dalam evalusi perlu dilibatkan khususnya yang terjadi di SMKN I Kedungwuni Pekalongan.

Kata kunci : pembelajaran, Collaborative Learning, Pendidikan Agama Islam

\section{PENDAHULUAN}

Pendidikan adalah usaha sadar dan terencana untuk mewujudkan suasana belajar dan proses pembelajaran agar peserta didik secara aktif mengembangkan potensi dirinya untuk memiliki kekuatan spiritual keagamaan, pengendalian diri, kepribadian, kecerdasan, akhlak mulia, serta ketrampilan yang diperlukan dirinya, masyarakat, bangsa dan Negara. ${ }^{1}$

Wina Sanjaya dalam menyikapi Undang-undang No. 20 Tahun 2003 menyebutkan bahwa ada beberapa hal penting yang terdapat dalam konsep pendidikan tersebut. ${ }^{2}$ Pertama, pendidikan adalah usaha sadar yang terencana. Hal ini berarti proses pendidikan di sekolah bukanlah proses yang dilaksanakan secara asal-asalan dan untung-untungan, akan tetapi proses yang bertujuan sehingga segala sesuatu yang dilakukan oleh pendidik dan peserta didik diarahkan pada pencapaian tujuan.

Kedua, proses pendidikan yang terencana itu diarahkan untuk mewujudkan suasana belajar dan proses pembelajaran. Hal ini berarti pendidikan tidak boleh mengesampingkan proses belajar. Pendidikan tidak semata-mata berusaha untuk mencapai hasil belajar, akan tetapi bagaimana memperoleh hasil atau proses belajar yang terjadi pada diri anak. Antara proses dan hasil belajar harus berjalan secara seimbang dalam pendidikan.

Ketiga, suasana belajar dan pembelajaran itu diarahkan agar peserta didik dapat mengembangkan potensi dirinya. Ini berarti proses pendidikan itu harus berorientasi kepada peserta didik (student active learning). Pendidikan adalah upaya pengembangan potensi anak didik, dengan demikian, anak harus dipandang sebagai organisme yang sedang berkembang dan memiliki potensi. Tugas pendidikan adalah mengembangkan potensi yang dimiliki anak

1 Undang-undang Republik Indonesia Nomor 20 Tahun 2003 tentang Sistem Pendidikan Nasiona

2 Wina Sanjaya, Strategi Pembelajaran Berorientasi Standar Proses Pendidikan, (Jakarta: Kencana Prenada Media Group, 2008), 2

2 | FENOMENA, Vol.19 No.1April 2020 
didik, bukan menjejalkan materi pelajaran atau memaksa agar anak dapat menghafal data dan fakta.

Keempat, akhir dari proses pendidikan adalah anak memiliki kekuatan spiritual keagamaan, pengendalian diri, kepribadian, kecerdasan, akhlak mulia serta ketrampilan yang diperlukan dirinya, masyarakat, bangsa dan negara. Hal ini berarti proses pendidikan berujung pada pengembangan kecerdasan atau intelektual, pembentukan sikap, serta pengembangan ketrampilan anak sesuai dengan kebutuhan. Ketiga aspek inilah (kecerdasan, sikap dan ketrampilan) arah dan tujuan yang harus selalu diupayakan. Ketika pendidik memberikan pelajaran Pendidikan Agama Islam, maka pendidik harus berfikir bagaimana mata pelajaran tersebut dapat membentuk anak memiliki kecerdasan, sikap dan ketrampilan sesuai dengan tujuan pendidikan.

Pendidikan bertujuan pada pencapaian perkembangan dan perubahan individual serta sosial secara utuh yang berlangsung dalam kehidupan. ${ }^{3}$ Pendidikan memerlukan perumusan tujuan pendidikan, identifikasi dan pengenalan potensi peserta didik, pemilihan strategi pembelajaran yang tepat dan evaluasi yang valid untuk mengukur sejauh mana tujuan pendidikan tersebut telah tercapai. Aktifitas-aktifitas tersebut harus dilakukan oleh pendidik untuk menghasilkan kualitas produk pendidikan yang baik sebagaimana yang diharapkan.

Kualitas produk pendidikan salah satunya ditentukan oleh pendidik dalam proses pembelajaran, beberapa ahli menyatakan, bahwa betapapun bagusnya suatu kurikulum (official), hasilnya sangat bergantung pada apa yang dilakukan oleh pendidik di dalam kelas (actual). Kualitas pembelajaran juga dipengaruhi oleh sikap pendidik yang kreatif untuk memilih dan melaksanakan berbagai pendekatan dan model pembelajaran, karena profesi pendidik menuntut sifat kreatif dan kemauan mengadakan improvisasi. ${ }^{4}$ Oleh karena itu pendidik harus selalu menumbuhkan dan mengembangkan sikap kreatifnya dalam mengelola pembelajaran, misalnya, dalam memilih dan menerapkan berbagai strategi, pendekatan, metode maupun media pembelajaran yang relevan dengan kondisi peserta didik dan tujuan pembelajaran Pendidikan Agama Islam.

3 Reja Mudyaharjo, Filsafat Ilmu Pendidikan, (Bandung: Remaja Rosdakarya,2006), 79

${ }^{4}$ Nana Syaodih Sukmadinata, Prinsip dan Landasan Pengembangan Kurikulum, (Jakarta: P2LPTK, 1983), 115 
Pendidikan Agama harus mampu mengantarkan peserta didik kepada terbinanya tiga aspek. Pertama, aspek keimanan yang mencakup seluruh rukun iman. Kedua, aspek ibadah yang mencakup seluruh rukun Islam. Ketiga, aspek akhlak yang mencakup seluruh akhlakul karimah. ${ }^{5}$

Selama ini kondisi Proses Belajar Mengajar masih banyak dikuasai oleh cara-cara tradisional, yaitu pendidik menyampaikan pelajaran, peserta didik mendengarkan atau mencatat dengan sistem evaluasi yang mengutamakan pengukuran kemampuan menjawab pertanyaan hafalan atau kemampuan verbal lainnya. Jika kondisi ini dibiarkan berlarut-larut terjadi dalam setiap lembaga pendidikan, maka pembelajaran tidak akan dapat tercapai dengan baik.

Pembelajaran diartikan sebagai setiap upaya yang sistematik dan disengaja oleh pendidik untuk menciptakan kondisi agar peserta didik melakukan kegiatan belajar. Kegiatan belajar ini menghasilkan interaksi edukatif antara dua pihak, yaitu antara peserta didik yang melakukan kegiatan belajar dengan pendidik yang melakukan kegiatan pembelajaran. ${ }^{6}$ Keberhasilan pembelajaran Pendidikan Agama Islam di sekolah ditentukan oleh strategi pembelajaran yang dilakukan oleh pendidik. Pendidik harus memiliki strategi dalam Proses Belajar Mengajar agar peserta didik dapat belajar secara efektif dan efisien, mengena pada tujuan yang diharapkan. ${ }^{7}$

Menyikapi hal tersebut, maka harapan yang selalu diinginkan oleh pendidik adalah bagaimana bahan pengajaran yang disampaikan dapat dikuasai oleh peserta didik secara tuntas. Ini merupakan sesuatu yang sulit dilakukan. Kesulitan itu dikarenakan peserta didik bukan hanya sebagai individu dengan segala keunikannya, tetapi mereka juga sebagai makhluk sosial dengan latar belakang yang berbeda. Paling tidak ada tiga aspek yang membedakan peserta didik yang satu dengan lainnya, yaitu aspek intelektual,

5 Putra Daulay Haidar, Pendidikan Islam: dalam Sistem Pendidikan Nasional di Indonesia, (Jakarta: Kencana Prenada Media Group, 2007), 38

6 Sudjana, , Metode dan Teknik Pembelajaran Partisipatif, (Bandung: Falah Production, 2001), 8

${ }^{7}$ Roestiyah, Strategi Belajar Mengajar, (Jakarta: Rineka Cipta, 2008), 1

4 | FENOMENA, Vol.19No.1April 2020 
psikologis dan biologis. ${ }^{8}$ Mengajar bukanlah hanya mentransfer pengetahuan dari pendidik kepada peserta didik, melainkan membantu peserta didik agar dapat mengkonstruksi sendiri pengetahuannyaa lewat kekuatan tehadap fenomena dan objek yang diketahui. ${ }^{9}$

Salah satu upaya untuk mewujudkan suasana belajar yang memungkinkan peserta didik berkomunikasi secara baik adalah dengan menggunakan pendekatan pendidikan yang berpusat pada peserta didik (student-centered approaches). Pendekatan pembelajaran yang berpusat pada peserta didik ini melahirkan pembelajaran Collaborative Learning. Pembelajaran Collaborative Learning merupakan salah satu bentuk dari pembelajaran Active Learning.

Active Learning adalah bentuk pembelajaran yang berorientasi pada pembentukan kreatifitas peserta didik sejak awal melalui aktifitas-aktifitas belajar. Realisasinya dalam pembelajaran, peserta didik dapat dikelompokkan dengan cara yang berbeda untuk tujuan yang berbeda, tugas-tugas dikerjakan dengan bekerja sama dalam kelompok-kelompok kecil, inilah yang dimaksud dengan pembelajaran Collaborative Learning.

Collaborative Learning merupakan salah satu dari pembelajaran aktif yang meliputi berbagai cara untuk membuat peserta didik aktif sejak awal melalui aktifitas-aktifitas yang membangun kerja kelompok dan dalam waktu yang singkat membuat mereka berpikir tentang materi pelajaran. ${ }^{1}$ Pembelajaran ini dirancang untuk memaksimalkan keberhasilan belajar secara kolaboratif dan meminimalkan kegagalan. Ketika peserta didik mulai mempelajari ketrampilan-ketrampilan kolaboratif, kelompok itu haruslah kelompok kecil. Sejalan dengan perkembangan ketrampilan sosial, peserta didik diharapkan mulai mampu bekerja sama dalam kelompok. Penting juga untuk melihat lamanya waktu kelompok itu akan bekerja sama. Pertemuan kelompok yang teratur dalam jangka waktu tertentu akan dapat meningkatkan kesuksesan

8 Syaiful Bahri Djamarah dan Aswan Zain, Strategi Belajar Mengajar, (Jakarta: Rineka Cipta, cet ke-3, 2006), 1

9 Jasa Ungguh Muliawan, Pendidikan Islam Integratif, (Yogyakarta: Pustaka Pelajar, 2005), 132

1 Silberman, Active Learning : 101 Strategi Pembelajaran Aktif, (Yogyakarta: YAPPENDIS, 2001), 16

FENOMENA, Vol.19No.1April 2020 | 5 
dibanding kelompok yang hanya bekerja sama kadang-kadang saja. Teknis pelaksanaan strategi ini diatur oleh pendidik ketika berada di dalam kelas.

Pembelajaran kelompok merupakan bentuk usaha pemberian bantuan kepada peserta didik yang lebih menekankan pada aspek afektif dan psikomotor disamping aspek kognitif. Hubungan antar peserta didik dapat menjadi wahana anggota kelompok (secara perorangan) untuk dapat memanfaatkan semua informasi, tanggapan dan berbagai reaksi dari kelompok lain untuk kepentingan dirinya yang berkaitan dengan pengembangan diri anggota kelompok.

Sisi lain, kesempatan mengemukakan pendapat, tanggapan dan berbagai reaksipun dapat merupakan peluang yang sangat berharga bagi individu yang bersangkutan. Kesempatan timbal balik inilah yang merupakan dinamika kelompok yang dapat membawa manfaat bagi seluruh anggota.

Berdasarkan kerangka pemikiran tersebut, penulis tertarik dan bermaksud melakukan pengkajian dalam bentuk penulisan terhadap "Pembelajaran Collaborative Learning dalam Pendidikan Agama Islam di SMK Ma'arif NU Tirto dan SMKN I Kedungwuni Pekalongan”. Pengambilan kedua lokasi tersebut untuk mengambil benang merah dari sisi implementasi pembelajaran Collaborative Learning ini.

\section{Active Learning dan Pembelajaran Collaborative Learning}

\section{Active Learning}

Pembelajaran aktif merupakan model pembelajaran yang lebih banyak melibatkan peserta didik dalam mengakses berbagai informasi dan pengetahuan untuk dibahas dan dikaji dalam pembelajaran di kelas, sehingga mereka mendapatkan berbagai pengalaman yang dapat meningkatkan kompetensinya. Selain itu belajar aktif juga memungkinkan peserta didik dapat mengembangkan kemampuan analisis dan sintesis serta mampu merumuskan nilai-nilai baru yang diambil dari hasil analisis mereka sendiri. Model ini hampir tidak jauh berbeda dengan model pembelajaran self discovery learning yakni pembelajaran yang dilakukan oleh peserta didik untuk menemukan kesimpulan sendiri sehingga dapat dijadikan sebagai nilai baru yang dapat diimplementasikan dalam kehidupan peserta didik. ${ }^{1}$

1 Khaeruddin dan Mahfud Junnaedi, Kurikulum Tingkat Satuan Pendidikan, Konsep dan Implementasinya di Madrasah, (Yogyakarta: MDC Jateng bekerja sama dengan Pilar Media, 2007), 209

6 | FENOMENA, Vol.19No.1April 2020 
Apa yang menjadikan belajar "aktif"? Silberman mengatakan:

When learning is active, students do most of the work. They use their brains....studying ideas, solving problem, and applying what they learn. Active Learning is fast-paced, fun, supportive, and personally engaging. Often, student are out of their seats, moving about and thinking aloud. ${ }^{1}$

Pernyataan tersebut menunjukkan bahwa pada saat kegiatan belajar aktif, peserta didik harus mengerjakan banyak tugas, mereka harus menggunakan otak, mengkaji gagasan, memecahkan masalah, dan menerapkan apa yang mereka pelajari. Belajar aktif merupakan langkah cepat, menyenangkan, bersemangat dan penuh gairah. Peserta didik bahkan sering meninggalkan tempat duduk, bergerak leluasa dan berfikir keras

Belajar aktif ditunjukkan dengan adanya keterlibatan intelektual dan emosional yang tinggi dalam proses belajar, tidak sekedar aktifitas fisik semata. ${ }^{1}$ Pembelajaran aktif (Áctive Learning) hanya bisa terjadi bila ada partisipasi aktif peserta didik. Demikian juga peran serta aktif peserta didik tidak akan terjadi bilamana pendidik tidak aktif dan kreatif dalam melaksanakan pembelajaran. Ada berbagai cara untuk melakukan proses pembelajaran yang memicu dan melibatkan peran serta aktif peserta didik dan mengasah ranah kognitif, afektif dan psikomotorik dan ranah imaniahtransendental. Proses pembelajaran aktif dalam memperoleh informasi, ketrampilan dan sikap serta prilaku positif dan terpuji akan terjadi melalui suatu proses pencarian dari diri peserta didik. Hal ini akan terwujud bila peserta didik dikondisikan sedemikian rupa sehingga berbagai tugas dan kegiatan yang dilaksanakan sangat memotivasi mereka untuk berfikir, bekerja dan merasa serta mengamalkan kesalehan dalam kehidupan nyata. ${ }^{1}$

Bagaimana menjadikan peserta didik aktif sejak awal? Pada saat-saat awal dari kegiatan belajar aktif ada tiga tujuan penting yang akan dicapai. Arti penting tujuan tersebut hendaknya tidak diabaikan sekalipun

1 Melvin Silberman, Active 2 Learning: 101 Strategies to Teach Any Subject, Nedham Heights, Massachusetts: by Allyn and Bacon, a Simon and Schuster Company, 1996, hlm. ix

1 Direktorat Ketenagaan Dirjen̉ Dikti Depdiknas, Pembelajaran Inovatif dan Partisipatif, 2007, 158

1 Ismail, Strategi Pembelajaran Agama Islam Berbasis PAIKEM, (Semarang: RaSAIL Media Group, 2008), 72 
pembelajarannya hanya berlangsung satu jam pelajaran. Silberman menyebutkan tujuan-tujuan tersebut sebagai berikut: ${ }^{1}$

a. Team building: Helping students to become acquainted with each other or creating a spirit of cooperation and interdependence

b. On the spot assessment: Learning about students attitudes, knowledge, and experience of students

c. Immediate learning involvement: Creating initial interest in the subject matter

Bahwa tujuan tersebut adalah: 1). Pembentukan tim: membantu peserta didik untuk lebih mengenal satu sama lain dan menciptakan semangat kerja sama dan interdependensi 2). Evaluasi sederhana: mempelajari tentang prilaku-prilaku, pengetahuan dan pengalaman peserta didik 3). Keterlibatan belajar langsung: menciptakan minat awal terhadap pelajaran

Ketiga tujuan di atas, bila dicapai akan membantu menciptakan lingkungan belajar yang melibatkan peserta didik, meningkatkan kemauan mereka untuk ambil bagian dalam kegiatan belajar aktif dan menciptakan norma kelas yang positif. Pelajaran yang berlangsung hingga dua jam sudah cukup memadai hanya dengan memakan waktu sekitar lima menit untuk mengalokasikan waktu pembuka. Memperkenalkan kembali aktifitas dari waktu ke waktu selama pelajaran juga akan membantu memperbarui pembentukan tim, memperbaiki evaluasi dan menciptakan kembali minat terhadap mata pelajaran.

Sementara itu Ismail menyebutkan prinsip-prinsip yang harus diperhatikan pendidik dalam menerapkan pembelajaran aktif (Active Learning) antara lain: ${ }^{1}$

1. Memahami sifat peserta didik

2. Mengenal peserta didik secara perorangan

3. Memanfaatkan prilaku peserta didik dalam pengorganisasian belajar

4. Mengembangkan kemampuan berfikir kritis dan kreatif serta mampu

5. Menciptakan ruangan kelas sebagai lingkungan belajar yang menarik

6. Memanfaatkan lingkungan sebagai lingkungan belajar

7. Memberikan umpan balik yang baik untuk meningkatkan kegiatan Membedakan antara aktif fisik dengan aktif mental

Silberman mengatakan bahwa dalam pembelajaran aktif bentuk-

1 Silberman, Active Learning: ${ }^{101}$ Cara Belajar Siswa Aktif, (Bandung: Nusamedia, 2006), 11

1 Ismail, Strategi Pembelajarań Agama Islam Berbasis PAIKEM, (Semarang: RaSAIL Media Group, 2008), 72

8 | FENOMENA, Vol.19 No.1April 2020 
bentuk yang dapat digunakan antara lain: ${ }^{1}$

1. Full-Class Learning (Proses belajar satu kelas penuh): pengajaran yang dipimpin oleh pendidik yang menstimulasi seluruh peserta didik

2. Class discussion (Diskusi kelas): dialog dan debat tentang persoalanpersoalan utama

3. Question prompting (Pengajuan pertanyaan): peserta didik meminta penjelasan

4. Collaborative Learning (belajar dengan cara bekerja sama): tugas-tugas dikerjakan dengan kerja sama dalam kelompok kecil peserta didik

5. Peer teaching (belajar dengan teman sebaya): Pengajaran yang dilakukan oleh peserta didik sendiri

6. Independent learning (Kegiatan Belajar Mandiri): aktifitas belajar yang dilakukan secara perseorangan

7. Affective learning (Kegiatan Belajar afektif): kegiatan yang membantu peserta didik memahami perasaan, nilai-nilai dan sikap mereka

8. Skill development (Pengembangan Ketrampilan): mempelajari dan mempraktekkan ketrampilan, baik teknis maupun non teknis.

Bentuk-bentuk tersebut disesuaikan dengan situasi dan kondisi individu peserta didik tersebut.

\section{Pembelajaran Collaborative Learning}

\section{a. Belajar, Pembelajaran dan Pembelajaran Collaborative Learning}

Sebelum membahas pembelajaran Collaborative Learning, penulis perlu memaparkan pengertian belajar dan pembelajaran agar memiliki pemahaman yang jelas sehingga perbedaan kedua istilah tersebut dapat diketahui, baik secara teoritis maupun praktis

Belajar dapat ditinjau dari dua segi yaitu belajar sebagai proses dan belajar sebagai hasil. Sebagai proses, belajar dapat diartikan upaya yang wajar melalui penyesuaian tingkah laku. Sebagai hasil, belajar adalah perubahan tingkah laku yang diperoleh dari kegiatan belajar. Perubahan tingkah laku sebagai hasil belajar itu mencakup ranah (domain) efeksi, kognisi dan psikomotor.

Belajar adalah memperoleh pengetahuan atau menguasai pengetahuan melalui pengalaman, mengingat, menguasai pengalaman dan mendapatkan

1 Silberman, Active Learning : ${ }^{7} 101$ Strategi Pembelajaran Aktif, (Yogyakarta: YAPPENDIS, 2001), 13

FENOMENA, Vol.19 No.1 April 2020 | 9 


\section{Mufasiroh}

informasi atau menemukan. Belajar memiliki arti dasar adanya aktifitas atau kegiatan dan penguasaan tentang sesuatu. ${ }^{1}$

Morris L. Bigge memberikan definisi belajar sebagai berikut: Learning is an enduring change in a living individual that is not heralded by a genetic inheritance. ${ }^{1}$

Belajar adalah perubahan yang menetap dalam diri seseorang yang tidak dapat diwariskan secara genetik. Selanjutnya Morris L. Bigge menyatakan bahwa perubahan itu terjadi pada pemahaman (insight), prilaku, persepsi, motivasi atau campuran dari semuanya secara sistematis sebagai akibat pengalaman dalam situasi-situasi tertentu.

Senada dengan pengertian tersebut, Mayer menyebutkan Learning is a relatively permanent change in a person's knowledge or behavior due to experience. ${ }^{2}$ Belajar adalah perubahan yang permanen pada diri seseorang berupa pengetahuan atau tingkah laku dari hasil pengalaman.

Whittaker menyebutkan Learning may be defined us the process by which behavior originates or is altered throught training or experience. ${ }^{2}$ Belajar adalah proses perubahan tingkah laku yang ditimbulkan atau diubah melalui latihan dan pengalaman. Beberapa definisi tersebut dapat penulis simpulkan bahwa belajar pada dasarnya adalah suatu proses menuju perubahan yang diinginkan melalui pengalaman atau latihan

Menurut Mulyasa pembelajaran pada hakekatnya adalah interaksi antara peserta didik dengan lingkungannya sehingga terjadi perubahan tingkah laku ke arah yang lebih baik. Pembelajaran dipengaruhi oleh faktor internal yang datang dari diri individu maupun faktor eksternal yang datang dari lingkungan individu tersebut. ${ }^{2}$

1 Baharuddin dan Esa Kur Wahyuni, Teori Belajar dan Pembelajaran, (Yogyakarta: Ar-Ruzz Media, 2007), 13

1 Bigge, Morris L dan Samuel Shermis, S., Learning Theories for Teachers, (New York: Harper Collins Publisher Inc, 1992), 1

2 Richard Mayer, Educational Psychology, a Cognitive Approach, (New York: Harper Collins Publishers, 1947), 87

2 James Whittaker, Introduction in Education, (New Delhi: Tata.Mc.Graw-Hill Publishing Ltd, 1997), 7

2 E. Mulyasa, Kurikulum ${ }^{2}$ Berbasis Kompetensi: Konsep, Karakteristik dan Implementasi, (Bandung: PT. Remaja Rosdakarya, 2004), 100

10 | FENOMENA, Vol.19 No.1April 2020 
Sedangkan pembelajaran, seperti didefinisikan adalah suatu kombinasi yang tersusun yang meliputi unsur-unsur manusiawi, internal material, fasilitas perlengkapan dan prosedur yang saling mempengaruhi untuk mencapai tujuan pembelajaran. ${ }^{2}$

Pembelajaran terkait dengan bagaimana membelajarkan peserta didik atau bagaimana membuat peserta didik dapat belajar dengan mudah dengan kemauannya sendiri untuk mempelajari apa yang teraktualisasikan dalam kurikulum. ${ }^{2}$

Edgar menyebutkan: Strategies of a new type must be adopted and aplied. The introduction of alternative educational strategies should be a feature of the present decade. ${ }^{2}$ Strategi yang baru ${ }_{5}^{5}$ selayaknya diadopsi dan diterapkan. Untuk mengantarkan pada suatu alternatif strategi pembelajaran harus disesuaikan dengan kondisi sekarang.

Kesimpulan yang dapat ditarik oleh penulis dari uraian tersebut bahwa belajar merupakan aktifitas yang dilakukan seseorang atau peserta didik secara pribadi dan sepihak, sedangkan pembelajaran melibatkan dua pihak, yaitu pendidik dan peserta didik yang di dalamnya mengandung dua unsur sekaligus, yaitu mengajar dan belajar (teaching and learning). Jadi dalam pembelajaran telah tercakup istilah belajar. Pendidik hendaknya memahami dan menghayati hakekat belajar dan pembelajaran secara benar. Pemahaman dan penghayatan tersebut dapat mengembangkan daya kreatifitas pendidik dalam menjalankan tugasnya.

Istilah Collaborative menurut Salim berasal dari kata col-lab-o-ra-tion yang berarti kerja sama. Collaborative Learning adalah pembelajaran dimana peserta didik dikelompokkan dengan cara bekerja sama sesuai kebutuhan. ${ }^{2}$ Berdasarkan jumlah peserta didik ada kelompok yang berjumlah, 4, 5, atau 6 peserta didik. Berdasarkan kemampuan intelektual, ada kelompok yang

2 Oemar Hamalik, Kurikulum daan Pembelajaran, (Jakarta: Bumi Aksara, 2001), 57

2 Muhaimin, Paradigma Pêndidikan Islam, (Bandung: PT. Remaja Rosdakarya, 2004), 145

2 Edgar Faure, Learning to Be: The World of Education Today and Tomorrow, (Paris: Unesco, 1972), 175

2 Peter Salim, Advanced, English-Indonesion Dictionary, (Jakarta: Modern English Press, 1991), 164 
bervariasi tingkat intelektualnya dan ada yang seimbang kelompok intelektualnya. $^{2}$

Proses belajar secara kolaborasi atau Collaborative Learning bukan sekedar bekerja sama dalam suatu kelompok tetapi penekanannya lebih kepada suatu proses pembelajaran yang melibatkan proses komunikasi secara utuh dan adil di dalam kelas. ${ }^{2}$

Pembelajaran Collaborative merupakan salah satu teknik intruksional yang diteliti secara cermat di Amerika Serikat. Ada banyak model, teori dan sumber dengan perspektif yang bermacam-macam dalam pembelajaran ini. Tinjauan dari berbagai penulisan menunjukkan bahwa metode ini dapat meningkatkan pencapaian belajar peserta didik, mempercepat pembelajaran, meningkatkan daya ingat dan memiliki hasil yaitu tindakan positif terhadap pembelajaran itu sendiri.

Collaborative Learning merupakan falsafah tentang tanggung jawab pribadi dan sikap menghormati sesama. Para peserta didik bertanggungjawab atas belajar mereka sendiri dan berusaha menemukan informasi untuk menjawab pertanyaan-pertanyaan yang dihadapkan kepada mereka. Pendidik bertindak sebagai fasilitator, memberikan dukungan tetapi tidak menyetir kelompok ke arah hasil yang sudah disiapkan sebelumnya. Bentukbentuk peer-assessment (asesmen oleh sesama peserta didik) digunakan untuk melihat hasil prosesnya. ${ }^{2}$

\section{Tujuan Pembelajaran Collaborative Learning}

Realitas pembelajaran cenderung berjalan secara statis, rutinitas dan monoton yang berakibat pada "kemandulan intelektual" peserta didik. Dalam proses pembelajaran seringkali memunculkan suasana yang tidak nyaman, menakutkan, stress bagi peserta didik. Kenyataan menyebabkan rasa kebencian peserta didik terhadap mata pelajaran yang akhirnya peserta didik sulit menerima materi pelajaran tertentu. Sebenarnya tidak ada materi pelajaran yang sulit, hanya karena faktor

2 Thoifuri, Menjadi Guru Inisiator, (Semarang: RaSAIL Media Group, 2007), 69

2 Adi W. Gunawan, Genius Leårning Strategy, Petunjuk Praktis untuk Menerapkan Accelerated Learning, (Jakarta: PT. Gramedia Pustaka Utama, 2006), 198

2 Daniel Muijs dan David Reynold, Effective Teaching, Teori dan Aplikasi, (Yogyakarta: Pustaka Pelajar, 2008), 89

12 | FENOMENA, Vol.19 No.1April 2020 
psikologis yang negatif, maka peserta didik akhirnya merasa kesulitan dalam memahami materi pelajaran tertentu

Sebenarnya perasaan seperti itu bukan karena materi pelajaran yang sulit tetapi lebih pada gaya penampilan pendidik selama pembelajaran tidak menarik atau menyenangkan peserta didik. Masih banyak pendidik pada saat pembelajaran menampilkan sosok manusia yang angker, sering melakukan intimidasi peserta didik, berlaku kasar pada peserta didik, memberikan hukuman tidak sesuai dengan nilainilai pendidikan.

Apa yang dipraktekkan pendidik itu secara tidak langsung sangat berpengaruh negatif bagi peserta didik dalam mempelajari dan mengembangkan pengetahuan serta kedewasaan pribadi peserta didik. Oleh karena itu, pembelajaran dalam konteks sekarang ini tidak cukup pembelajaran yang efektif, tetapi justru yang amat penting adalah pembelajaran yang efisien, yaitu pembelajaran yang menyenangkan, menggairahkan, penuh keakraban dan saling menghargai antara pendidik dan peserta didik. Hal ini merupakan tujuan dari pembelajaran Collaborative Learning. ${ }^{3}$

Pembelajaran Collaborative Learning termasuk pembelajaran kontekstual yang berusaha untuk memberdayakan potensi yang ada dalam diri peserta didik baik potensi intelektual (kognitif), potensi moral kepribadian (afektif) dan potensi ketrampilan mekanik (psikomotorik).

2. Unsur dan Elemen dalam Pembelajaran Collaborative Learning

Campbell dkk. mengemukakan dua komponen penting dari Collaborative Learning, yaitu:

a. Individual Accountability. A group's success is based on each member's ability to demonstrate that he or she has learned the required material.

3 Saekhan Muchith, Pembelajaran Kontekstual, (Semarang: RaSAIL Media Group, 2008), 8

FENOMENA, Vol.19 No.1April 2020 | 13 
b. Positive Interdependence. The success of the group depends on its ability to work together to achieved desired result such as recognition, grades reward or free time. ${ }^{3}$ 1

Keberhasilan kelompok pada pertanggungjawaban individual didasarkan pada kemampuan setiap anggota untuk menunjukkan bahwa peserta didik telah belajar materi-materi yang sangat dibutuhkan. Sementara itu, keberhasilan kelompok pada ketergantungan positif didasarkan atas kemampuan kelompok dalam bekerja sama untuk meraih hasil yang diinginkan. Misalnya: ketenaran (pengakuan), tingkat penghargaan, dan waktu luang.

Slavin dalam pandangannya menyatakan:

Collaborative activity among children promotes growth because children of similar ages are likely to be operating within one another's proximal zones of development, modeling in the collaborating group behaviors more advanced than those they could perform as individuals. ${ }^{3}$

Kegiatan kolaboratif antara anak-anak yang usianya sebaya lebih suka bekerja di dalam wilayah pembangunan paling dekat sama satu sama lain, prilaku yang diperlihatkan di dalam kelompok kolaborasi lebih berkembang daripada yang dapat mereka tunjukkan sebagai individu.

Gunawan menyebutkan lima elemen penting yang ada dalam Collaborative Learning, ${ }^{3}$ yaitu:

a. Interdependen yang positif (perasaan kebersamaan)

b. Interaksi face to face atau tatap muka yang saling mendukung (saling membantu, saling menghargai, memberikan selamat dan merayakan sukses bersama)

c. Tanggung jawab individual dan kelompok (demi keberhasilan pembelajaran)

3 Linda Campbell Bruce Câmpbell, dan Dee Dickinson, Teaching and Learning Through Multiple Intelligences, (Boston: by Allyn and Bacon, 1948), 159

3 Robert E. Slavin, E. Robert, Cooperative Learning: Theory, Research and Practice, (Needham Heights, Massachusetts: by Allyn and Bacon, a Simon and Schuster Company, 1995), 17

3 Adi W. Gunawan, Genius Leärning Strategy, Petunjuk Praktis untuk Menerapkan Accelerated Learning, (Jakarta: PT. Gramedia Pustaka Utama, 2006), 199

14 | FENOMENA, Vol.19 No.1April 2020 
d. Kemampuan komunikasi antarpribadi dan komunikasi dalam suatu kelompok kecil (komunikasi, rasa percaya, kepemimpinan, pembuatan keputusan dan manajemen serta resolusi konflik)

e. Pemprosesan secara kelompok (melakukan refleksi terhadap fungsi dan kemampuan mereka bekerja sama sebagai suatu kelompok dan bagaimana untuk membantu berprestasi lebih baik lagi)

\section{Cara Mengefektifkan Pembelajaran Collaborative Learning.}

Menurut Muijs dan Reynold, kerja kelompok kecil Collaborative yang efektif membutuhkan persiapan yang cukup signifikan dan sejumlah prasyarat yang harus dipenuhi untuk mengefektifkannya. Peserta didik harus mampu bekerja sama dan saling memberikan bantuan secara konstruktif. Sejumlah studi menemukan bahwa collaborative berhubungan positif dengan prestasi bila interaksi kelompoknya bersifat saling menghormati dan inklusif, dan berhubungan negatif dengan prestasi bila interaksi kelompok tidak saling menghormati atau tidak setara. ${ }^{3}$

Hal ini tentu bukan berarti sesuatu yang given, karena banyak (khususnya peserta didik yang masih muda dan peserta didik dengan latar belakang yang sangat kurang menguntungkan) ditemukan kurang memiliki ketrampilan sosial yang dibutuhkan untuk berinteraksi secara positif dengan teman-teman sebayanya.

Gunawan menyebutkan cara yang bisa dilakukan pendidik untuk mengefektifkan proses pembelajaran Collaborative di dalam kelas, sebagai berikut: ${ }^{3}$

a. Pengelompokan yang dilakukan dengan menggunakan acuan level kemampuan harus dilakukan secara hati-hati.

b. Jumlah anggota kelompok harus diusahakan sedikit.

c. Collaborative Learning harus diterapkan secara konsisten dan sistematik, tetapi tidak boleh digunakan secara berlebihan.

\footnotetext{
3 Daniel Muijs dan David Reynold, Effective Teaching, Teori dan Aplikasi, (Yogyakarta: Pustaka Pelajar, 2008), 34

3 Adi W. Gunawan, Genius Leárning Strategy, Petunjuk Praktis untuk Menerapkan Accelerated Learning, (Jakarta: PT. Gramedia Pustaka Utama, 2006), 199
} 
Santrock mengemukakan bahwa pembelajaran Collaborative dapat menjadi pembelajaran yang efektif untuk meningkatkan prestasi, terutama jika terpenuhi dengan dua syarat, ${ }^{3}$ yaitu:

a. Disediakan penghargaan kepada kelompok.

b. Individu dimintai pertanggungjawaban

Pendidik dapat melakukan beberapa variasi teknik pengelompokan untuk menghindari kebosanan dan efek rutinitas dalam melakukan Collaborative Learning. Salah satu cara untuk memberikan variasi dalam pengelompokan tersebut adalah dengan menggunakan tiga jenis kelompok berikuti: ${ }^{3}$

a. Informal

Kelompok informal adalah kelompok yang bersifat sementara. Pengelompokan ini hanya digunakan dalam satu periode pengajaran. Kelompok ini biasanya hanya terdiri dari dua orang peserta didik.

b. Formal

Kelompok formal digunakan untuk memastikan bahwa peserta didik mempunyai cukup waktu untuk menyelesaikan tugas dengan baik. Lamanya kelompok ini bekerja bisa selama beberapa hari atau bahkan beberapa minggu tergantung pada tugas atau proyek yang diberikan kepada mereka.

c. Pendukung

Kelompok pendukung adalah pengelompokan dengan tenggang waktu yang lebih panjang (misalnya selama satu semester atau satu tahun). Tujuannya adalah memberi suatu dukungan yang berkelanjutan kepada peserta didik.

\section{HASIL}

\section{Perencanaan/Persiapan Pembelajaran Collaborative Learning}

3 John W Santrock, John, Psikologi Pendidikan, (Jakarta: Kencana Prenada Media Group, 2007), 397

3 Adi W. Gunawan, Genius Ledrning Strategy, Petunjuk Praktis untuk Menerapkan Accelerated Learning, (Jakarta: PT. Gramedia Pustaka Utama, 2006), 200

16 | FENOMENA, Vol.19 No.1April 2020 
Tahap persiapan yang dilakukan oleh pendidik Pendidikan Agama Islam di SMK Ma'arif dan SMKN I Kedungwuni Pekalongan:

\section{a. Menyusun Prota/Promes}

Prota adalah Program Tahunan yang disusun oleh pendidik untuk satu tahun pelajaran tertentu. Pembelajaran yang menggunakan sistem semester berarti dalam satu tahun pelajaran terdiri dari dua semester. Program ini yang dipakai oleh SMK Ma'arif NU Tirto dan SMKN I Kedungwuni Pekalongan untuk tahun pelajaran 2017/2018.

Promes adalah Program Semester yang dibuat pendidik sebagai acuan untuk melaksanakan pembelajaran dalam satu semester. Program Semester berisi Kompetensi atau sub kompetensi yang akan diajarkan dalam satu semester sesuai dengan alokasi waktu yang direncanakan. Pada program semester juga tercantum kolom bulan yang harus diisi oleh pendidik untuk masa pembelajaran selama satu semester.

Program Tahunan (Prota) dan Program Semester (Promes) adalah rencana umum pembelajaran mata pelajaran setelah diketahui kepastian jumlah jam pelajaran efektif dalam satu tahun atau semester. Penyusunan Prota dan Promes ini didasarkan hasil analisis alokasi waktu yang ditetapkan sebelumnya dan hasil pemetaan kompetensi dasar per unit (Muslich, 2008: 44). Program tahunan ini memuat alokasi waktu untuk setiap kompetensi dalam satu tahun pelajaran, sedangkan program semester memuat alokasi waktu untuk setiap kompetensi dalam satu semester (Suryobroto, 2002: 30). Program Tahunan dan Program Semester perlu disusun secara rinci dan sistematis.

\section{b. Menyusun Silabus}

Silabus yang terdapat di SMK Ma'arif NU Tirto dan SMKN I Kedungwuni Pekalongan, secara rinci dapat penulis paparkan sebagai berikut:

1) Sebagai pedoman dalam pengembangan rancangan dan pelaksanaan pembelajaran lebih lanjut, seperti pembuatan rencana pembelajaran, pengelolaan kegiatan pembelajaran dan pengembangan sistem evaluasi. Silabus ini merupakan pokok dalam penyusunan rencana pembelajaran, baik rencana untuk satu standar kompetensi maupun satu kompetensi dasar

FENOMENA, Vol.19 No.1April 2020 | 17 
2) Sebagai pedoman untuk merencanakan pengelolaan kegiatan pembelajaran, dalam hal ini adalah pembelajaran dalam kelompok kecil kolaboratif

3) Untuk pengembangan sistem evaluasi. Sistem evaluasi dalam pelaksanaan pembelajaran Kurikulum Tingkat Satuan Pendidikan selalu mengacu pada Standar Kompetensi, Kompetensi Dasar dan materi pokok/pembelajaran yang terdapat dalam silabus.

\section{c. Menyusun Rencana Pelaksanaan Pembelajaran (RPP)}

Format Rencana pembelajaran Pendidikan Agama Islam di SMK Ma'arif NU Tirto, dapat penulis paparkan sebagai berikut: Mata Pelajaran, Kelas / Semester, Pertemuan ke, Alokasi Waktu, Standar Kompetensi, Kompetensi Dasar, Indikator Tujuan Pembelajaran, Materi, Metode Pembelajaran, Skenario Pembelajaran, Alat/bahan/sumber bahan, Evaluasi.

Kedua Rencana Pelaksanaan Pembelajaran (RPP) tersebut yang menunjukkan perbedaan adalah istilah skenario pembelajaran dipakai di SMK Ma'arif NU Tirto, sedangkan di SMKN I Kedungwuni Pekalongan menggunakan langkah-langkah kegiatan pembelajaran. Sekalipun istilah yang dipakai berbeda namun pada dasarnya kedua istilah tersebut samasama berisi rancangan strategi yang akan dilaksanakan dalam pembelajaran Collaborative Learning. Rencana pembelajaran tersebut akan memudahkan proses yang akan dilaksanakan dalam pembelajaran Collaborative Learning.

\section{Pelaksanaan Pembelajaran Collaborative Learning}

Secara umum keaktifan peserta didik dalam mengikuti pembelajaran Collaborative Learning di SMK Ma'arif NU Tirto dan SMKN I Kedungwuni Pekalongan ini dapat diklasifikasikan menjadi dua:

1. Peserta didik yang sejak awal mulai pembelajaran Collaborative Learning sampai berakhir pembelajaran senantiasa aktif berpartisipasi dalam kelompok. Indikatornya terlihat tampak antusias menyelesaikan tugas-tugas yang diberikan dalam kelompok dengan baik. Jumlah peserta didik di SMK Ma'arif NU Tirto yang termasuk kategori ini ada 24 dari 30 peserta didik, sehingga yang temasuk kategori sekitar $80 \%$, sedangkan di SMKN I Kedungwuni Pekalongan yang termasuk kategori ini ada 29 dari 36 peserta didik, sehingga yang termasuk kategori ini

18 | FENOMENA, Vol.19 No.1April 2020 
Implementasi Pembelajaran Collaborative Learning......

kurang lebih ada 80,56 \% dari seluruh peserta didik di kelas yang bersangkutan

2. Peserta didik yang kadang-kadang tampak memperhatikan dan mengikuti pembelajaran tetapi sering pula berbicara sendiri dengan teman-teman. Kelompok ini akan kembali mengikuti pembelajaran dengan baik manakala ditegur dan disapa oleh pendidik. Jumlah peserta didik di SMK Ma'arif NU Tirto yang termasuk kategori ini ada 6 dari 30 peserta didik, sehingga yang termasuk kategori ini sekitar $20 \%$, sedangkan di SMKN I Kedungwuni Pekalongan jumlah ini lebih kecil yaitu 7 dari 36 peserta didik, sehingga yang termasuk kategori ini sekitar 19, 44 $\%$ dari jumlah peserta didik dalam satu kelas.

Berdasarkan pelaksanaan Collaborative Learning di SMK Ma'arif NU Tirto dan SMKN I Kedungwuni Pekalongan, maka faktor pendukung yang menjadi dampak positif dalam Collaborative Learning ini antara lain:

1. Dapat memberikan kesempatan bertanya kepada para peserta didik untuk menggunakan ketrampilan bertanya dan membahas suatu masalah

2. Dapat memberikan kesempatan kepada para peserta didik untuk lebih intensif mengadakan penyelidikan mengenai suatu kasus atau masalah

3. Dapat mengembangkan bakat kepemimpinan dan mengajarkan kertampilan berbicara

4. Para peserta didik lebih aktif tergabung dalam pelajaran mereka, dan mereka akan lebih aktif berpartisipasi dalam kelompok

5. Dapat memberi kesempatan kepada para peserta didik untuk mengembangkan rasa menghargai dan menghormati pribadi temannya, menghargai pendapat orang lain, mereka telah saling membantu kelompok dalam usahanya mencapai tujuan bersama

6. Dapat memungkinkan pendidik untuk lebih memperhatikan peserta didik sebagai individu serta kebutuhan belajarnya

Disamping itu, setelah melaksanakan proses pembelajaran pada kedua sekolah tersebut, maka faktor penghambat yang menjadi dampak negatif dari Collaborative Learning adalah:

FENOMENA, Vol.19 No.1April 2020 | 19 
a. Strategi ini kadang menuntut pengaturan tempat duduk yang berbeda-beda

b. Kerja kelompok Collaborative sering hanya melibatkan kepada peserta didik yang mampu sebab mereka cakap memimpin dan mengarahkan peserta didik yang kurang

c. Keberhasilan strategi kerja kelompok ini tergantung kepada kemampuan peserta didik memimpin kelompok atau untuk bekerja sendiri

Kelemahan atau sisi negatif ini dapat diminimalisir dengan cara antara lain:

1. Mejelaskan tugas kepada peserta didik

2. Menjelaskan apa tujuan dari kerja kelompok tersebut

3. Membagi peserta didik menjadi beberapa kelompok dengan seefektif mungkin

4. Setiap kelompok menunjuk seorang pencatat yang akan membuat laporan tentang kemajuan dan hasil kelompok tersebut

5. Pendidik berkeliling selama kerja kelompok itu berlangsung bila perlu memberi saran/pertanyaan

6. Pendidik membantu menyimpulkan kemajuan dan menerima hasil kerja kelompok.

\section{Evaluasi Pembelajaran Collaborative Learning}

Setelah proses pembelajaran Collaborative Learning selesai, maka tahap selanjutnya adalah tahap evaluasi. Pada tahap evaluasi ini, berdasarkan observasi yang penulis lakukan di SMK Ma'arif NU Tirto dan SMKN I Kedungwuni Pekalongan menunjukkan bahwa evaluasi dilakukan dengan menggunakan evaluasi proses dan evaluasi hasil, adapun alat evaluasi yang digunakan adalah pengamatan

Evaluasi proses Collaborative Learning di SMK Ma'arif NU Tirto dilakukan selama pembelajaran berlangsung. Evaluasi proses ini dilakukan selama pembelajaran dengan mengamati sikap, ketrampilan dan kemampuan berfikir serta berkomunikasi peserta didik. Kesungguhan mengerjakan tugas, hasil eksplorasi, kemampuan berfikir kritis dan logis dalam memberikan pandangan atau argumentasi, kemauan untuk bekerja sama dan memikul tanggungjawab bersama merupakan aspek yang dinilai selama proses pembelajaran berlangsung. Sesekali pendidik memancing dengan memberi umpan pertanyaan kepada beberapa peserta didik. Cara ini dil-

20 | FENOMENA, Vol.19 No.1April 2020 
akukan untuk memberi dorongan peserta didik agar lebih serius terhadap tugas yang harus diselesaikan. Ketika penulis menanyakan lebih jauh kepada pendidik ternyata evaluasi proses itu berfungsi sebagai motivator agar peserta didik dapat bekerja sama lebih baik dalam kelompok.

Evaluasi proses di SMKN I Kedungwuni Pekalongan dilakukan selama kerja kelompok berlangsung dari awal sampai akhir, caranya dengan membuat daftar evaluasi yang sudah disiapkan sebelumnya. Khulaefah, S.Ag, selaku pendidik mengamati setiap gerak, prilaku dan aktifitas peserta didik tanpa berhenti, kadang dilakukan dengan duduk, namun terkadang dilakukan juga sambil berkeliling untuk memastikan aktifitas peserta didik dalam kelompok. Pendidik disamping berperan sebagai fasilitator juga merangkap menjadi evaluator yang aktif mengamati peserta didik. Terlihat pendidik tidak pernah berhenti memandang dan mengamati peserta didik sambil berkeliling mengawasi jalannya kerja kelompok.

Evaluasi hasil belajar oleh pendidik dilakukan dengan menggunakan berbagai teknik evaluasi berupa praktek atau tes kinerja, observasi selama pembelajaran berlangsung dan/atau diluar kegiatan pembelajaran, penugasan perorangan atau kelompok dan bentuk lain yang sesuai dengan karakteristik kompetensi dan tingkat perkembangan peserta didik. Evaluasi hasil belajar yang dilakukan di SMK Ma'arif NU Tirto dan SMKN I Kedungwuni Pekalongan tidak jauh berbeda, yaitu menggunakan bentuk praktek atau tes perbuatan dengan cara melakukan presentasi di depan kelas.

\section{KESIMPULAN}

Berpijak pada beberapa fenomena empiris yang teramati dalam pelaksanaaan pembelajaran di SMK Ma'arif NU Tirto dan SMKN I Kedungwuni Pekalongan, penulis mengambil kesimpulan secara umum bahwa kedua sekolah tersebut menggunakan Collaborative Learning sebagai salah satu strategi dalam pembelajaran Pendidikan Agama Islam di sekolah masing-masing. Implementasi pembelajaran tersebut dilaksanakan dengan menggunakan 3 tahap, yaitu tahap persiapan, tahap pelaksanaan dan tahap evaluasi. Secara rinci penulis mengambil kesimpulan sebagai berikut:

Tahap persiapan yang dilakukan oleh pendidik Pendidikan Agama Islam di SMK Ma'arif NU Tirto dan SMKN I Kedungwuni Pekalongan merupakan upaya untuk mempersiapkan kegiatan pembelajaran yang akan 
dilaksanakan. Persiapan yang dilakukan antara lain: menyusun Prota/Promes, menyusun Silabus dan menyusun RPP. Strategi yang dikembangkan pada tahap persiapan ini tidak lagi terfokus pada kegiatan pendidik semata (teacher centered) namun sudah berorientasi kepada kepentingan peserta didik (student centered). Bentuk pembelajaran seperti itu merupakan salah satu model pembelajaran yang diinginkan dalam implementasi Kurikulum Tingkat Satuan Pendidikan (KTSP).

Oleh karena itu, persiapan yang dilakukan oleh pendidik menjadi acuan atau standar dalam proses pembelajaran. Bermakna atau tidak proses pembelajaran yang akan dilaksanakan sangat tergantung dari rencana yang dibuat. Prota/Promes, Silabus dan RPP yang sesuai dengan muatan kurikulum akan memberi kemudahan pendidik dalam mengimplementasikan rencana yang dibuat menjadi lebih bermakna

Pelaksanaan Collaborative Learning di SMK Ma'arif NU Tirto dan SMKN I Kedungwuni Pekalongan merupakan implementasi dari rancangan kegiatan pembelajaran yang telah disusun oleh pendidik Pendidikan Agama Islam yang terdapat di dalam Program Tahunan/Program Semester (Prota/Promes), Silabus dan Rencana Pelaksanaan Pembelajaran (RPP).

Keaktifan peserta didik dalam Collaborative Learning ini didukung oleh minat yang besar untuk mengikuti pembelajaran. Hal ini bukan berarti bahwa Collaborative Learning yang dilakukan tidak menemui kendala/hambatan dalam pelaksanaan. Secara garis besar penulis simpulkan bahwa baik di SMK Ma'arif NU Tirto maupun di SMKN I Kedungwuni Pekalongan hambatan terbesar yang dialami peserta didik dalam Collaborative Learning adalah kesulitan berkomunikasi secara lisan untuk mengemukakan pendapat. Problem ini berdampak terhadap peserta didik pada saat melakukan presntasi di depan kelompok lain.

Oleh karena itu, pendidik harus menyadari bahwa pelaksanaan srategi pembelajaran dengan jenis apapun termasuk Collaborative Learning tidak akan terlepas dari hambatan/kendala yang ditemui pada waktu pelaksanaan. Bagaimana usaha pendidik untuk meminimalisir kendala tersebut menjadi salah satu kunci keberhasilan pendidikan. Keberhasilan pendidik menciptakan situasi yang nyaman merupakan jembatan bagi keberhasilan peserta didik dalam proses pembelajaran.. 
Evaluasi Collaborative Learning di SMK Ma'arif NU Tirto dan SMKN I Kedungwuni menggunakan evaluasi proses dan evaluasi hasil. Hal ini sesuai dengan tuntutan pembelajaran aktif yang tidak hanya memperhatikan hasil namun juga sangat menekankan pada proses

Oleh karena itu, alternatif lain yang perlu dikembangkan pada tahap evaluasi ini adalah menggabungkan antara nilai individu dan nilai kelompok. Nilai individu dapat diambil dari proses pembelajaran sedangkan nilai kelompok dapat diambil dari rata-rata nilai semua anggota kelompok yang ditampilkan melalui presentasi. Dengan cara ini kelompok dapat berusaha lebih keras untuk membantu semua anggota dalam pelaksanaan evaluasi

\section{DAFTAR PUSTAKA}

Baharuddin dan Esa Nur Wahyuni, 2007, Teori Belajar dan Pembelajaran, Yogyakarta: Ar-Ruzz Media

Campbell, Linda, Bruce Campbell, dan Dee Dickinson, 1948, Teaching and Learning Through Multiple Intelligences, Boston: by Allyn and Bacon

Direktorat Ketenagaan Dirjen Dikti Depdiknas, 2007, Pembelajaran Inovatif dan Partisipatif

Djamarah, Syaiful Bahri dan Aswan Zain, 2006, Strategi Belajar Mengajar, Jakarta: Rineka Cipta

Faure, Edgar, 1972, Learning to Be: The World of Education Today and Tomorrow, Paris: Unesco

Gunawan, Adi W., 2006, Genius Learning Strategy, Petunjuk Praktis untuk Menerapkan Accelerated Learning, Jakarta: PT. Gramedia Pustaka Utama

Haidar, Putra Daulay, 2007, Pendidikan Islam: dalam Sistem Pendidikan Nasional di Indonesia, Jakarta: Kencana Prenada Media Group

Hamalik, Oemar, 2001, Kurikulum dan Pembelajaran, Jakarta: Bumi Aksara

Ismail, 2008, Strategi Pembelajaran Agama Islam Berbasis PAIKEM, Semarang: RaSAIL Media Group

Khaeruddin dan Mahfud Junaedi, 2007, Kurikulum Tingkat Satuan Pendidikan, Konsep dan Implementasinya di Madrasah, Yogyakarta: MDC Jateng bekerja sama dengan Pilar Media

Mayer, Richard, 1947, Educational Psychology, a Cognitive Approach, New York: Harper Collins Publishers

FENOMENA, Vol.19 No.1April 2020 | 23 


\section{Mufasiroh}

Whittaker, James, 1997, Introduction in Education, New Delhi: Tata.Mc.GrawHill Publishing Ltd

Morris L, Bigge dan Samuel Shermis, S., 1992, Learning Theories for Teachers, New York: Harper Collins Publisher Inc

Muchith, Saekhan, 2008, Pembelajaran Kontekstual, Semarang: RaSAIL Media Group

Muhaimin, 2004, Paradigma Pendidikan Islam, Bandung: PT. Remaja Rosdakarya.

Muijs, Daniel dan David Reynold, 2008, Effective Teaching, Teori dan Aplikasi, Yogyakarta: Pustaka Pelajar

Muliawan, Jasa Ungguh, 2005, Pendidikan Islam Integratif, Yogyakarta: Pustaka Pelajar

Mulyasa, E, 2004, Kurikulum Berbasis Kompetensi: Konsep, Karakteristik dan Implementasi, Bandung: PT. Remaja Rosdakarya

Reja Mudyaharjo, Reja, 2006, Filsafat Ilmu Pendidikan, Bandung: Remaja Rosdakarya

Roestiyah, 2008, Strategi Belajar Mengajar, Jakarta: Rineka Cipta

Salim, Peter, 1991, Advanced, English-Indonesion Dictionary, Jakarta: Modern English Press

Sanjaya, Wina, 2008, Strategi Pembelajaran Berorientasi Standar Proses Pendidikan, Jakarta: Kencana Prenada Media Group

Santrock, John W, 2007, John, Psikologi Pendidikan, Jakarta: Kencana Prenada Media Group

Silberman, Melvin, 1996, Active Learning: 101 Strategies to Teach Any Subject, Nedham Heights, Massachusetts: by Allyn and Bacon, a Simon and Schuster Company

--------, 2001, Active Learning : 101 Strategi Pembelajaran Aktif, Yogyakarta: YAPPENDIS

--------, 2006, Active Learning: 101 Cara Belajar Siswa Aktif, Bandung: Nusamedia

Slavin, Robert, 1995, Cooperative Learning: Theory, Research and Practice, Needham Heights, Massachusetts: by Allyn and Bacon, a Simon and Schuster Company

Sudjana, 2001, Metode dan Teknik Pembelajaran Partisipatif, Bandung: Falah Production

24 | FENOMENA, Vol.19 No.1April 2020 
Implementasi Pembelajaran Collaborative Learning......

Sukmadinata, Nana Syaodih, 1983, Prinsip dan Landasan Pengembangan Kurikulum, Jakarta: P2LPTK

Thoifuri, 2007, Menjadi Guru Inisiator, Semarang: RaSAIL Media Group

Undang-undang Republik Indonesia Nomor 20 Tahun 2003 tentang Sistem Pendidikan Nasional. 